\title{
Implementation of Government Regulation Number 33 of 2012 concerning Exclusive Breastfeeding as a Form of Legal Protection for Babies Against the Promotion of Infant Formula Milk in Palembang City
}

\author{
Implementasi Peraturan Pemerintah Nomor 33 Tahun 2012 Tentang Pemberian Asi Eksklusif \\ Sebagai Bentuk Perlindungan Hukum Bagi Bayi Terhadap Promosi Susu Formula Bayi Di \\ Kota Palembang
}

Anastasya Megasstuti Gunadi, Endang Widyorini, Yovita Indrayati email: anesmg@ymail.com

Health Law Master Program, Soegijapranata Catholic University of Semarang

\begin{abstract}
Exclusive Breast Milk became the important programs prioritized by the Government with the Government Regulation Number 33 the Year 2012 about giving breast milk exclusively, in which the Government bans activities deemed to inhibit Exclusive breast feeding program, in particular, the promotion of baby formula. The purpose of this research is to know the implementation of government regulations Number 33 the Year 2012 of Exclusive breast feeding as a form of legal protection for infants against the promotion of baby formula in Palembang; restricting factor and factor endowments as well as the responsibility of the Government of the city of Palembang in the implementation of government regulations Number 33 Year 2012 of Exclusive breast feeding as a form of legal protection for infants against the promotion of baby formula in the city of Palembang.

In this study, the author uses empirical juridical approach/sociological. This research is a descriptive analytic study. The analysis used in the study of qualitative analysis. Method of data collection used is through fieldwork using interviews and observations as well as through the study of librarianship by way of reading, collecting and studying as well as understand the source library.
\end{abstract}

The results of this study are: (1) the implementation of PP No. 33 Year 2012 of Exclusive breast feeding has not been run with optimal in providing legal protection for infants against the promotion of baby formula in Palembang (2) supporting factors in the implementation of the Government Regulation No. 33 Year 2012 of Exclusive breast feeding as a form of legal protection for infants against the promotion of baby formula in Palembang is a city of Palembang has had local regulations Exclusive Breast Milk that is governing local regulations No. 2 the year 2014 of Exclusive breast feeding. While the factors restricting among other social and cultural factors in the community, working mothers, a lack of manpower counselors trained in hospitals (3) The responsibility of the Government of the city of Palembang Area Regulations run number 2 Year 2014 of Exclusive breast feeding as a follow-up of the Government Regulation (PP) number 33 Year 2012 of Exclusive breast feeding and run the application of sanctions $a$ firm and tangible for those who violate and inhibit Exclusive breast feeding.

Keywords: Implementation, PP. 33 The year 2012, Exclusive Breast Milk, Promotion of Infant Formula 


\section{PENDAHULUAN}

Anak termasuk bayi adalah bagian dari generasi muda sebagai salah satu sumber daya manusia yang merupakan potensi dan penerus cita-cita perjuangan bangsa. Di dalam diri anak melekat harkat dan haknya sebagai manusia yang harus dijunjung tinggi. Agar setiap anak kelak mampu memikul tanggung jawab sebagai penerus cita-cita perjuangan bangsa, maka ia perlu mendapat kesempatan yang seluas-luasnya untuk tumbuh dan berkembang secara optimal, baik fisik, mental maupun sosial, dan berakhlak mulia, sehingga perlu dilakukan upaya perlindungan, serta untuk mewujudkan kesejahteraan anak dengan memberikan jaminan terhadap pemenuhan hak-haknya serta adanya perlakuan tanpa diskriminasi.

Untuk mewujudkan perlindungan dan kesejahteraan anak diperlukan dukungan kelembagaan dan peraturan perundang-undangan yang dapat menjamin pelaksanaannya. Pemerintah Indonesia telah mengundangkan Undang-Undang Nomor 4 Tahun 1979 tentang Kesejahteraan Anak dan Undang-Undang Nomor 23 Tahun 2002 tentang Perlindungan Anak sebagaimana telah diubah dengan Undang-Undang Nomor 35 Tahun 2014. Undang-Undang tersebut mewujudkan segala kegiatan untuk menjamin dan melindungi anak dan hakhaknya agar dapat hidup, tumbuh, berkembang, dan berpartisipasi secara optimal sesuai dengan harkat dan martabat kemanusiaan, serta mendapat perlindungan dari kekerasan dan diskriminasi.

Upaya perlindungan anak terdapat dalam berbagai aspek bidang kehidupan terutama upaya perlindungan anak dalam bidang kesehatan. Kesehatan merupakan aspek penting dari hak asasi manusia yang harus dijaga dan diupayakan. Namun hal ini masih menjadi masalah utama yang sering dijumpai di tengah masyarakat, angka kesakitan dan angka kematian pada bayi tiap tahun terus bertambah, berdasarkan data yang diperoleh Angka Kematian Bayi di Indonesia tahun 2012 diestimasi sebesar 32 per 1.000 kelahiran hidup, sedangkan untuk Provinsi Sumatera Selatan sebesar 29 per 1.000 kelahiran hidup (SDKI, 2012). Untuk Kota Palembang, berdasarkan laporan program anak, jumlah kematian bayi di tahun 2014 sebanyak 52 kematian bayi dari 29.235 kelahiran hidup (Profil Seksi Pelayanan Kesehatan Dasar, 2015). ${ }^{1}$

Hal ini dikarenakan masih banyak bayi yang tidak mendapatkan ASI dengan berbagai faktor penyebab, antara lain disebabkan oleh perubahan sosial, ekonomi dan budaya masyarakat, juga disebabkan oleh gencarnya promosi susu formula, ${ }^{2}$ sehingga berakibat anak tidak mendapatkan asupan gizi yang cukup, menurunnya daya kerja fisik dan kekebalan tubuh bayi serta terganggunya perkembangan mental. Pemenuhan nutrisi yang baik pada bayi adalah dengan memberikan Air susu ibu (ASI). ASI merupakan makanan bayi dengan standar emas yang terbukti mempunyai keunggulan yang tidak dapat digantikan oleh makanan dan minuman apapun.

ASI Eksklusif begitu penting bagi bayi sebagai penerus generasi bangsa sehingga harus dipayungi oleh hukum. WHO dan UNICEF telah menyatakan bahwa ASI Eksklusif merupakan sumber makanan yang terbaik bagi bayi. Kedua lembaga ini menyatakan bahwa ASI Eksklusif harus diberikan sampai bayi berumur 6 (enam) bulan. Hal tersebut juga dinyatakan dalam Keputusan Menteri Kesehatan Republik Indonesia Nomor 450/MENKES/SK/IV/2004 Tahun 2004. Kebijakan nasional terkait pemberian ASI Eksklusif telah ditetapkan oleh

\footnotetext{
${ }^{1}$ Profil Kesehatan Kota Palembang Tahun 2014.

${ }^{2}$ A. Mustofa, dan H. Prabandari, “Pemberian ASI Eksklusif dan Problematika Ibu Menyusui”, 2010, Yinyang, Vol 5 No 2 Jul-Des 2010 ISSN: 1907-2791.
} 
Pemerintah Indonesia dengan dikeluarkannya Peraturan Pemerintah Nomor 33 Tahun 2012 tentang Pemberian Air Susu Ibu Eksklusif. Peraturan Pemerintah Nomor 33 Tahun 2012 ini diterbitkan atas amanat Pasal 129 ayat (2) Undang-Undang Nomor 36 Tahun 2009 tentang Kesehatan. Peraturan pemerintah ini dimaksudkan untuk menjamin dan melindungi pemenuhan hak para bayi mendapatkan sumber makanan yang terbaik, sejak dilahirkan sampai berusia 6 (enam) bulan. Sementara susu formula apapun, tidak boleh diberikan kepada bayi yang baru lahir dengan dalih apapun kecuali atas indikasi medis tertentu.

Kota Palembang sendiri juga telah memiliki Peraturan Daerah tentang Pemberian ASI Eksklusif yaitu Peraturan Daerah Kota Palembang Nomor 2 Tahun 2014 tentang Pemberian ASI Eksklusif. Tujuan pemberlakuan peraturan daerah ini adalah untuk memberikan jaminan perlindungan pada bayi dalam mendapatkan ASI Eksklusif di Kota Palembang. Di Kota Palembang cakupan pemberian ASI Eksklusif Tahun 2014 hanya sebesar 74,18\%. ${ }^{3}$ Cakupan pemberian ASI Eksklusif di Kota Palembang masih di bawah target pencapaian pemberian ASI Eksklusif Indonesia yaitu 80\%. Permasalahan terkait pencapaian ASI Eksklusif antara lain promosi susu formula masih gencar dilakukan untuk bayi o- 6 bulan yang tidak ada indikasi medis, masih banyaknya tenaga kesehatan ditingkat layanan yang belum peduli atau belum berpihak pada pemenuhan hak bayi untuk mendapatkan ASI Eksklusif yaitu masih mendorong untuk memberikan susu formula pada bayi o- 6 bulan. ${ }^{4}$

Peningkatan penggunaan susu formula salah satunya disebabkan oleh orang tua terutama ibu lebih memilih memberikan bayi mereka Pengganti Air Susu Ibu (PASI) karena terpengaruh iklan dari media massa yang semakin merambat luas. ${ }^{5}$ Faktor pengiklanan susu formula di media masa dan media cetak dapat menghambat program ASI Eksklusif di Indonesia. Hal ini dikarenakan promosi-promosi susu formula tersebut mengakibatkan ibu cenderung memberikan susu formula dibandingkan dengan ASI Eksklusif. Sebagai makanan terbaik bagi bayi, ternyata ASI belum sepenuhnya dimanfaatkan oleh masyarakat, bahkan terdapat kecenderungan terjadi pergeseran penggunaan susu formula pada sebagian kelompok masyarakat. Maraknya Promosi susu formula untuk bayi di media massa, baik cetak maupun elektronik bahkan oleh tenaga kesehatan dapat menghambat program ASI Eksklusif di Indonesia. Hal ini dikarenakan promosi susu formula tersebut mengakibatkan ibu cenderung memberikan susu formula dibandingkan ASI Eksklusif. ${ }^{6}$

ASI Eksklusif menjadi program penting yang diprioritaskan oleh pemerintah. Dengan adanya Peraturan Pemerintah Nomor 33 Tahun 2012 tentang Pemberian Air Susu Ibu Eksklusif, yang di dalamnya pemerintah melarang kegiatan-kegiatan yang dianggap menghambat program pemberian ASI Eksklusif, khususnya promosi susu formula bayi. Pemerintah memiliki tanggung jawab dan peran yang sangat berarti dalam melindungi dan mendukung pemberian ASI sebagai usaha meningkatkan derajat kesehatan bayi karena Air Susu Ibu (ASI) merupakan makanan yang paling baik dan tepat untuk pertumbuhan dan perkembangan yang sehat bagi bayi, sehingga penggunaannya perlu dilindungi dan ditingkatkan secara aktif. Bayi perlu mendapatkan perlindungan hukum terutama pada masa bayi baru lahir sampai berusia 12 (dua belas) bulan dalam kaitannya dengan promosi

\footnotetext{
3 Profil Kesehatan Kota Palembang Tahun 2014.

${ }^{4}$ Profil Kesehatan Indonesia Tahun 2013.

${ }^{5}$ Arifin Siregar, 2004, Faktor-Faktor yang Mempengaruhi Pemberian ASI Oleh Ibu Melahirkan [serial online]. Medan: Bagian Gizi Kesehatan Masyarakat Fakultas Kesehatan Masyarakat Universitaas Sumatra Utara. http://library,usu.ac.id/download/ fkm/fkm-arifin-pdf. [diakses 13 Januari 2017]

${ }^{6}$ Briawan Dodik, 2004, Op. Cit, hal. 2-6.
} 
susu formula. Atas dasar itulah penulis merasa tertarik untuk melakukan penelitian guna menyusun tesis dengan judul "Implementasi Peraturan Pemerintah Nomor 33 Tahun 2012 Tentang Pemberian ASI Eksklusif Sebagai Bentuk Perlindungan Hukum Bagi Bayi Terhadap Promosi Susu Formula Bayi di Kota Palembang".

\section{PERUMUSAN MASALAH}

Berdasarkan latar belakang masalah yang telah diuraikan diatas, maka rumusan masalah yang akan teliti yaitu:

1. Bagaimana implementasi Peraturan Pemerintah Nomor 33 Tahun 2012 tentang Pemberian ASI Eksklusif sebagai bentuk perlindungan hukum bagi bayi terhadap promosi susu formula bayi di Kota Palembang?

2. Bagaimana faktor pendukung dan faktor penghambat dalam implementasi Peraturan Pemerintah Nomor 33 Tahun 2012 tentang Pemberian ASI Eksklusif sebagai bentuk perlindungan hukum bagi bayi terhadap promosi susu formula bayi di Kota Palembang?

3. Bagaimana tanggung jawab Pemerintah Kota Palembang dalam implementasi Peraturan Pemerintah Nomor 33 Tahun 2012 tentang Pemberian ASI Eksklusif sebagai bentuk perlindungan hukum bagi bayi terhadap promosi susu formula bayi di Kota Palembang?

\section{METODE PENELITIAN}

Dalam penelitian ini penulis menggunakan metode pendekatan yuridis empiris/sosiologis, yaitu akan membahas aspek yuridis dan sekaligus membahas aspek-aspek sosial yang melingkupi gejala hukum tertentu. Pada penelitian hukum sosiologis, maka yang diteliti awalnya adalah data sekunder untuk kemudian dilanjutkan dengan penelitian terhadap data primer studi lapangan atau terhadap masyarakat. ${ }^{7}$ Pendekatan yuridis sosiologis pada penelitian ini diawali dengan terlebih dahulu melakukan kajian terhadap data sekunder yaitu dengan menginventaris peraturan perundangan dan kajian pustaka tentang perlindungan hukum, ASI Eksklusif dan pelaksanaan Peraturan Pemerintah. Setelah semua data sekunder terkumpul, maka selanjutnya peneliti melakukan kajian terhadap implementasi Peraturan Pemerintah Nomor 33 Tahun 2012 tentang Pemberian ASI Eksklusif sebagai bentuk perlindungan hukum bagi bayi terhadap promosi susu formula bayi di Kota Palembang.

Spesifikasi penelitian ini merupakan penelitian deskriptif analitis. Penelitian ini bersifat deskriptif karena dimaksudkan untuk memberikan data seteliti mungkin tentang keadaan dan gejala-gejala lainnya. ${ }^{8}$ Dengan demikian yang menjadi fokus dalam penelitian ini adalah untuk memberikan analisis dan deskripsi berupa gambaran tentang implementasi Peraturan Pemerintah Nomor 33 Tahun 2012 tentang Pemberian ASI Eksklusif sebagai bentuk perlindungan hukum bagi bayi terhadap promosi susu formula bayi di Kota Palembang.

Jenis data yang digunakan dalam penelitian ini adalah: data primer yaitu data yang berasal dari sumber pertama melalui studi lapangan, adapun cara memperoleh data primer yakni melalui pengamatan/observasi mengenai program dan fasilitas pendukung ASI Eksklusif yang ada di Rumah Sakit Kota Palembang serta melakukan wawancara dalam bentuk daftar pertanyaan dengan informan penelitian yakni Kepala Dinas Kesehatan Kota Palembang

\footnotetext{
7 Soerjono Soekanto, 1986, Pengantar Penelitian Hukum, Jakarta: Penerbit Universitas Indonesia, hal. 52.

${ }^{8}$ Soerjono Soekanto, 2015, Pengantar Penelitian Hukum Cetakan Ketiga, Jakarta: Penerbit Universitas Indonesia, hal 17.
} 
diwakili Kepala Bidang Pelayanan Kesehatan, Direktur Rumah Sakit Umum Daerah BARI Palembang (Rumah Sakit Pemerintah) dan Rumah Sakit Myria Palembang (Rumah Sakit Swasta), tenaga kesehatan di Rumah Sakit Umum Daerah BARI Palembang (1 dokter kandungan, 1 dokter anak, dan 1 bidan) dan tenaga kesehatan di Rumah Sakit Myria Palembang (1 dokter kandungan, 1 dokter anak, dan 1 bidan), dan 8 ibu nifas yang menyusui yang memiliki bayi berusia 0-6 bulan yang menjalani perawatan di Rumah Sakit selama penelitian berlangsung. Data sekunder adalah data yang diperoleh melalui studi kepustakaan, guna untuk mendapatkan landasan teoritis berupa pendapat-pendapat atau tulisan para ahli atau pihak yang berwenang dan juga untuk memperoleh informasi baik dalam bentuk formal maupun naskah resmi yang ada. Data sekunder dalam penelitian ini berupa kepustakaan yaitu: Bahan/sumber hukum primer dan Bahan/sumber hukum sekunder.

Metode pengumpulan data yang digunakan dalam penelitian ini adalah: Studi lapangan yaitu cara mengumpulkan data primer yang dilakukan secara langsung pada obyeknya di lapangan. Data primer dikumpulkan dengan cara wawancara dan pengamatan. Studi kepustakaan ialah cara mengumpulkan data yang bertujuan untuk memperoleh data sekunder yaitu data yang diperoleh melalui bahan kepustakaan. Analisis yang digunakan dalam penelitian ini analisis kualitatif dengan menggunakan teori hukum tentang hak, perlindungan hukum dan implementasi kebijakan. Metode analisis kualitatif yakni analisis yang dilakukan untuk data yang tidak bisa dihitung, bersifat monografis atau berwujud kasus-kasus (sehingga tidak dapat disusun ke dalam suatu struktur klasifikatoris). Setelah data dikumpulkan, maka diperiksa/diteliti kembali untuk mencari kebenarannya dan hasil analisis tersebut kemudian disajikan secara deskriptif analitik yaitu gambaran bagaimana implementasi Peraturan Pemerintah Nomor 33 Tahun 2012 tentang Pemberian ASI Eksklusif sebagai bentuk perlindungan hukum bagi bayi terhadap promosi susu formula bayi di Kota Palembang.

\section{PEMBAHASAN}

\section{Gambaran Umum Kota Palembang}

Kota Palembang adalah ibukota Provinsi Sumatera Selatan yang mempunyai luas wilayah 400,61 km2 dengan jumlah penduduk 1.611.309 jiwa, yang berarti setiap km2 dihuni oleh 4.022 jiwa. Kota Palembang dibelah oleh Sungai Musi menjadi dua daerah yaitu Seberang Ilir dan Seberang Ulu. Sungai Musi ini bermuara ke Selat Bangka dengan jarak $\pm 105 \mathrm{Km}$. Oleh karena itu, perilaku air laut sangat berpengaruh yang dapat dilihat dari adanya pasang surut antara $3-5$ meter. $^{9}$

Untuk mewujudkan derajat kesehatan di Kota Palembang yang optimal, haruslah didukung oleh sumber daya manusia tenaga kesehatan, sarana dan prasarana kesehatan, pembiayaan kesehatan yang memadai, serta kebijakan pembangunan kesehatan untuk melaksanakan berbagai program yang dapat memberikan kontribusi positif bagi kesehatan terutama bagi lingkungan dan perilaku masyarakat. Agar dapat melaksanakan pelayanan kesehatan terhadap masyarakat di kota Palembang, saat ini pemerintah telah melengkapi sarana dan prasarana kesehatan yaitu : Rumah Sakit Mohammad Hosein Palembang di Kecamatan Kemuning, Rumah Sakit Umum Daerah (RSUD) Palembang Bari yang terletak di Seberang Ulu, dan rumah sakit swasta lainnya

\footnotetext{
${ }^{9}$ Dinas Kesehatan Kota Palembang, 2016, Profil Kesehatan Kota Palembang, Palembang, hal. 5
} 
serta 39 Puskesmas dan 70 Puskesmas Pembantu. Dengan keberadaan rumah sakit pemerintah dan swasta lainnya, masyarakat dapat menikmati pelayanan kesehatan secara optimal. ${ }^{10}$

\section{Pembahasan}

1. Implementasi Peraturan Pemerintah No. 33 Tahun 2012 tentang Pemberian ASI Eksklusif sebagai Bentuk Perlindungan Hukum bagi Bayi terhadap Promosi Susu Formula Bayi di Kota Palembang

ASI mempunyai manfaat yang besar bagi bayi karena memiliki efek positif terhadap pertumbuhan dan perkembangan. Bayi yang mendapatkan ASI akan lebih sehat dan terhindar dari berbagai penyakit infeksi. Hal inilah yang dapat menurunkan Angka Kematian Bayi. Berdasarkan aspek hukum, pemberian ASI eksklusif berarti memenuhi hak anak untuk hidup sehat sejahtera lahir dan batin. Dalam Pasal 28B ayat (2) Undang-Undang Dasar 1945 memuat bahwa, "setiap anak berhak atas kelangsungan hidup, tumbuh dan berkembang serta berhak atas perlindungan dari kekerasan dan diskriminasi."

Hak anak berupa hak atas tumbuh dan berkembang salah satunya dengan mendapatkan ASI. Undang-Undang Dasar 1945 secara tegas menjelaskan ada hak anak dalam hal ini termasuk bayi, untuk mendapatkan asupan makanan yang sesuai dengan perkembangan fisiknya. Dengan demikian bayi berhak mendapatkan ASI agar bayi dapat tumbuh dan berkembang dengan baik. ${ }^{11}$

Berdasarkan hal tersebut, pemerintah mengeluarkan peraturan yang menjamin hak anak untuk mendapatkan ASI, seperti yang tertuang dalam Undang-undang Nomor 36 Tahun 2009 Tentang Kesehatan serta Peraturan Pemerintah Nomor 33 Tahun 2012 tentang ASI Eksklusif yang berisikan kebijakan nasional pemberian ASI. Peraturan Pemerintah ini dimaksudkan untuk menjamin pemenuhan hak bayi mendapatkan sumber makanan terbaik. Selain itu, bentuk perlindungan hak anak lainnya terhadap promosi susu formula yang tidak hanya melalui media cetak dan elektronik, tetapi juga melalui tenaga kesehatan.

Berdasarkan hasil penelitian yang didapatkan untuk Kota Palembang sendiri telah memiliki Peraturan Daerah yang mengatur ASI Eksklusif yakni Peraturan Daerah Nomor 2 Tahun 2014 tentang Pemberian ASI Eksklusif, dimana sebelumnya juga telah ada Perwali No. 60 Tahun 2012 yang mengatur pemberian ASI Eksklusif di Kota Palembang. Peraturan Daerah Nomor 2 Tahun 2014 tentang Pemberian ASI Eksklusif tersebut merupakan tindak lanjut dari Peraturan Pemerintah Nomor 33 Tahun 2012 tentang ASI Eksklusif.

Dengan dikeluarkannya Peraturan Daerah Kota Palembang Nomor 2 Tahun 2014 tentang Pemberian ASI Eksklusif sebagai peraturan pelaksanaan dari Peraturan Pemerintah Nomor 33 Tahun 2012 tentang ASI Eksklusif berarti Kota Palembang telah melaksanakan kebijakan mengenai pemberian ASI Eksklusif. Peraturan Daerah Kota Palembang Nomor 2 Tahun 2014 tentang Pemberian ASI Eksklusif dan Peraturan Pemerintah Nomor 33 Tahun 2012 tentang ASI Eksklusif terdapat kesesuaian baik dalam isi implementasinya di lapangan, dikarenakan isi dari Peraturan Daerah Kota

\footnotetext{
${ }^{10}$ Ibid

${ }^{11}$ Suradi R., 2008, Manfaat ASI \& Kerugian Susu Formula, Jakarta: Balai Penerbit FKUI, hal. 25
} 
Palembang Nomor 2 Tahun 2014 tentang Pemberian ASI Eksklusif mengacu pada Peraturan Pemerintah Nomor 33 Tahun 2012 tentang ASI Eksklusif.

Berdasarkan hasil penelitian melalui wawancara dan kenyataan dilapangan serta teori yang dipakai terkait dengan Implementasi Peraturan Pemerintah No. 33 Tahun 2012 tentang Pemberian ASI Eksklusif di Kota Palembang, didapatkan bahwa Pemerintah Kota Palembang khususnya Dinas Kesehatan Kota Palembang telah melaksanakan berbagai kegiatan yang mendukung program ASI Eksklusif sesuai Peraturan Pemerintah No. 33 Tahun 2012 tentang Pemberian ASI Eksklusif, kegiatan yang telah dilaksanakan seperti advokasi dan sosialisasi mengenai program ASI Eksklusif dimana telah bekerjasama dengan beberapa instansi perusahaan yang memiliki tenaga kerja wanita serta organisasi profesi bidang kesehatan (IBI dan IDI) dan swadaya masyarakat di bidang ASI (Ayah ASI).

Advokasi dan sosialisasi yang telah dilakukan oleh Dinas Kesehatan Kota Palembang tersebut masih belum berjalan dengan optimal karena sosialisasi masih sebatas sarana umum milik pemerintah sedangkan sarana umum milik swasta belum dilakukan. Dinas Kesehatan Kota Palembang juga telah melaksanakan pelatihan teknis konseling menyusui pada 52 orang konselor ASI di Kota Palembang, namun sebarannya belum merata pada seluruh sarana kesehatan beberapa ada di rumah sakit dan puskesmas, untuk konselor ASI di sarana umum belum ada.

Terkait dengan promosi susu formula yang dapat menghambat program ASI Eksklusif di Kota Palembang pihak Dinas Kesehatan telah mensosialisasikan kepada seluruh fasilitas kesehatan dan tenaga kesehatan agar dalam penggunaan susu formula hanya digunakan atas indikasi medis serta diperlukannya informed consent pemberian susu formula dan harus dicatat dalam pelaporan rekam medis. Berdasarkan pengawasan dalam pencatatan dan pelaporan penggunaan susu formula bayi oleh tenaga kesehatan dan fasilitas pelayanan kesehatan sejauh ini pengawasan belum berjalan maksimal karena pelaporan belum berjalan secara rutin dan merata di seluruh fasilitas kesehatan.

Untuk mensosialisasikan dan mengantisipasi tindakan masyarakat yang dapat menghambat program ASI Eksklusif pihak Dinas Kesehatan juga telah berupaya menyebarkan/menempelkan leaflet mengenai aturan dan sanksi denda bagi yang menghambat pemberian ASI Eksklusif sesuai ketentuan pidana yang tertulis pada Pasal 37 Perda No. 2 Tahun 2014 Tentang Pemberian ASI Eksklusif serta membuka layanan pengaduan program ASI Eksklusif. Pengawasan terhadap promosi susu formula dimasyarakat juga belum berjalan optimal karena hanya sebatas menunggu apabila ada pengaduan dari masyarakat ataupun organisasi profesi kesehatan.

Berdasarkan hasil penelitian melalui wawancara dan kenyataan dilapangan serta teori yang dipakai terkait dengan Implementasi Peraturan Pemerintah No. 33 Tahun 2012 tentang Pemberian ASI Eksklusif di Kota Palembang, didapatkan bahwa di dua Rumah Sakit yang menjadi Obyek penelitian telah menerima sosialisasi PP dan Perda mengenai ASI Eksklusif dari Dinas Kesehatan Kota Palembang. Rumah Sakit dalam implementasi PP ASI Eksklusif telah melaksanakan pemberian ASI Eksklusif dimana petunjuk pelaksanaannya mengacu pada sepuluh langkah menuju keberhasilan menyusui menurut Kepmenkes No.450/MENKES/SK/IV/2004 tentang Pemberian ASI secara Eksklusif. Implementasi Sarana Prasarana ASI Eksklusif di dua Rumah Sakit sudah cukup baik dengan telah tersedianya fasilitas yang mendukung program ASI Eksklusif yakni diantaranya adanya proses IMD dan rawat gabung, tersedianya ruang 
menyusui bahkan salah satu dari obyek penelitian telah memiliki klinik laktasi dan konselor yang khusus membantu menolong ibu yang memiliki permasalahan menyusui.

Untuk ketersediaan tenaga konselor di dua obyek penelitian Rumah Sakit ini didapatkan penyebarannya kurang merata dimana ditemukan tenaga konselor lebih banyak dimiliki oleh Rumah Sakit milik pemerintah dibandingkan Rumah Sakit swasta hal ini dikarenakan kurang maksimalnya kegiatan ataupun sosialisasi pelatihan teknis konseling menyusui dan tenaga konselor yang diadakan oleh Dinas Kesehatan Kota Palembang. Terkait dengan Peraturan mengenai larangan fasilitas kesehatan mempromosikan susu formula sudah diterapkan oleh pihak Rumah Sakit. Rumah Sakit tidak setuju dan menolak segala bentuk tawaran kerjasama dari provider susu formula hal ini dibuktikan dengan salah satu obyek penelitian RSUD BARI berkomitmen tidak menyediakan stok susu formula di Rumah Sakitnya sedangkan untuk RS Myria masih ada menyediakan stok susu formula apabila akan digunakan dalam keadaan darurat saja.

Rumah Sakit sudah melaksanakan pencatatan dan pelaporan penggunaan susu formula bayi sesuai sosialisasi Dinas Kesehatan dimana dalam setiap penggunaannya dicatat didalam rekam medik pasien dengan menyertakan informed consent penggunaan susu formula. Monitoring pembinaan dan pengawasan dari Dinas Kesehatan berkaitan dengan promosi susu formula di Rumah Sakit masih belum berjalan optimal karena dari keterangan kunjungan visitasi ke Rumah Sakit belum merata dan rutin terjadwal dilakukan.

Berdasarkan hasil penelitian melalui wawancara dan kenyataan dilapangan serta teori yang dipakai terkait dengan Implementasi Peraturan Pemerintah No. 33 Tahun 2012 tentang Pemberian ASI Eksklusif di Kota Palembang, didapatkan bahwa tenaga kesehatan telah melaksanakan program ASI Eksklusif yakni memberikan KIE ASI Eksklusif kepada ibu hamil dan menyusui, melakukan IMD serta Rawat Gabung. Beberapa tenaga kesehatan yang diteliti masih ada yang belum mendapatkan sosialisasi pelatihan konseling sehingga dalam pelaksanaannya hanya bermodalkan dari pengetahuan pribadi saja hal tersebut membuktikan bahwa Dinas Kesehatan belum secara optimal melaksanakan pelatihan konseling ataupun tenaga konselor.

Tenaga kesehatan telah mengetahui sanksi larangan mempromosikan susu formula bayi dan dalam penggunaan susu formula bayi tenaga kesehatan sudah meminta persetujuan serta pencatatan direkam medik. Terkait monitoring pembinaan dan pengawasan sanksi larangan mempromosikan susu formula oleh tenaga kesehatan sejauh ini hanya berupa pembinaan saja dari pihak Rumah Sakit.

Berdasarkan hasil penelitian melalui wawancara dan kenyataan dilapangan serta teori yang dipakai terkait dengan Implementasi Peraturan Pemerintah No. 33 Tahun 2012 tentang Pemberian ASI Eksklusif di Kota Palembang, didapatkan bahwa ibu nifas yang diteliti telah memiliki pengetahuan mengenai ASI Eksklusif hal tersebut sesuai dengan hasil yang ditemukan bahwa ibu nifas sudah pernah mendapatkan penjelasan mengenai ASI Eksklusif dari tenaga kesehatan sehingga dapat mempengaruhi pengetahuan mengenai ASI Eksklusif ibu nifas tersebut. Ibu nifas juga sudah mengetahui mengenai susu formula bayi, namun dalam pengetahuan ibu nifas mengenai kandungan antara susu formula bayi dan ASI terdapat perbedaan pendapat hal tersebut disebabkan oleh tingkat pendidikan dan wawasan dari ibu nifas itu sendiri. 
Terkait tawaran promosi dari produk susu formula bayi didapatkan sebagian besar ibu nifas yang diteliti pernah mendapatkan promosi tersebut dari produsen susu. Ibu nifas selama dirawat di Rumah Sakit tempat obyek penelitian sudah pernah diberikan penjelasan dari tenaga kesehatan tentang penggunaan susu formula yang hanya diperbolehkan apabila ada masalah indikasi medis dan tidak boleh langsung diberikan setelah bayi lahir.

Pemberian susu formula dan produk bayi lainnya atas indikasi medis yang dilakukan oleh petugas kesehatan diutamakan untuk penyelamatan nyawa. Memberikannya juga harus dengan menggunakan resep dokter. Untuk produk susu formula bayi adalah susu yang memang secara khusus diformulasikan sebagai pengganti ASI untuk bayi sampai berusia 6 (enam) bulan. Hal tersebut sesuai dengan Pasal 12 Peraturan Daerah Kota Palembang Nomor 2 Tahun 2014 tentang Pemberian ASI Eksklusif yang menyatakan bahwa dalam hal pemberian ASI Eksklusif tidak dimungkinkan berdasarkan pertimbangan sebagaimana dimaksud dalam Pasal 4 ayat (1), bayi dapat diberikan Susu Formula Bayi sesuai dengan kondisi bayi. Lebih lanjut yang dimaksud dengan ibu tidak ada dan ibu terpisah dari bayi adalah ibu meninggal dunia, ibu tidak diketahui keberadaannya, ibu terpisah dari bayi karena ada bencana atau kondisi lainnya dimana ibu terpisah dengan bayinya sehingga ibu tidak dapat memenuhi kewajibannya atau anak tidak memperoleh haknya. ${ }^{12}$

Sebenarnya Tenaga kesehatan menghadapi keadaan dilema dimana adanya aturan yang melarang tenaga kesehatan mempromosikan susu formula bayi lebih ditekankan kepada tenaga kesehatan, padahal dalam hal ini faktor dari produsen dan ibu itu sendiri sangat besar. Tidak ada sanksi yang tegas terhadap produsen yang melakukan promosi susu formula tidak sesuai aturan. Produsen harus diberi aturan ketat dalam menyalurkan susu formula bayi, dan tenaga kesehatan tidak bisa berbuat banyak ketika keputusan untuk menggunakan susu formula bayi kembali kepada ibu. Oleh karena itu, pihak Rumah Sakit membuat surat pernyataan yang berisi tentang permintaan ibu untuk memberikan susu formula bayi kepada anaknya. Surat penyataan ini bertujuan untuk menghindari hal-hal yang akan menimbulkan kerugian di kedua belah pihak. Hal ini sesuai dengan Pasal 14 Peraturan Menteri Kesehatan Nomor 39 Tahun 2013 tentang Susu Formula Bayi dan Produk Bayi Lainnya yang menyatakan bahwa dalam hal terjadi indikasi medis, dokter atau rumah sakit harus mendapat persetujuan ibu bayi/keluarganya terlebih dulu untuk memberikan susu formula. Persetujuan itu diberikan setelah ibu bayi/keluarganya mendapatkan penjelasan dan peragaan terlebih dulu atas penggunaan dan penyajian susu formula.

Sanksi administrasi tidak ditujukan pada konsumen pada umumnya, tetapi justru kepada pengusaha, baik itu produsen maupun para penyalur hasil-hasil produknya. Sanksi administratif berkaitan dengan perizinan yang diberikan Pemerintah RI kepada pengusaha/penyalur tersebut. Jika terjadi pelanggaran, izin-izin itu dapat dicabut secara sepihak oleh Pemerintah. Sanksi administratif seringkali lebih efektif dibandingkan dengan sanksi perdata atau pidana. Ada beberapa alasan untuk mendukung pernyataan ini.

Pertama, sanksi administratif dapat diterapkan secara langsung dan sepihak. Dikatakan demikian karena penguasa sebagai pihak pemberi izin tidak perlu meminta

${ }^{12}$ Pasal 7 Peraturan Pemerintah Nomor 33 Tahun 2012 tentang Pemberian ASI Eksklusif 
persetujuan terlebih dahulu dari pihak manapun. Persetujuan, kalaupun itu dibutuhkan, mungkin dari instansi-instansi Pemerintah terkait. Sanksi administratif juga tidak perlu melalui proses pengadilan. Memang, bagi pihak yang terkena sanksi ini dibuka kesempatan untuk membela diri, antara lain mengajukan kasus tersebut ke Pengadilan Tata Usaha Negara, tetapi sanksi itu sendiri dijatuhkan terlebih dalu, sehingga berlaku efektif.

Kedua, sanksi perdata dan/atau pidana acapkali tidak membawa efek jera bagi pelakunya. Nilai ganti rugi dan pidana yang dijatuhkan mungkin tidak seberapa dibandingkan dengan keuntungan yang diraih dari perbuatan negatif produsen. Belum lagi mekanisme penjatuhan putusan itu yang biasanya berbelit-belit dan membutuhkan proses yang lama, sehingga konsumen sering menjadi tidak sabar. Untuk gugatan secara perdata, konsumen juga dihadapkan posisi tawar menawar yang tidak selalu menguntungkan dibandingkan dengan si produsen.

Berdasarkan uraian yang ada didapatkan bahwa implementasi PP No. 33 Tahun 2012 Tentang Pemberian ASI Eksklusif belum berjalan dengan optimal dalam memberikan perlindungan hukum bagi bayi terhadap promosi susu formula bayi di Kota Palembang hal tersebut terlihat dari sistem mekanisme pembinaan, pengawasan, dan penegakan hukum sanksi yang belum jelas dan tegas dari Pemerintah (Dinas Kesehatan Kota Palembang), BPOM, dan organisasi profesi kesehatan.

2. Faktor Pendukung dan Faktor Penghambat dalam Implementasi Peraturan Pemerintah No. 33 Tahun 2012 tentang Pemberian ASI Eksklusif sebagai Bentuk Perlindungan Hukum bagi Bayi terhadap Promosi Susu Formula Bayi di Kota Palembang

Implementasi adalah suatu rangkaian aktifitas dalam rangka menghantarkan kebijakan peraturan kepada masyarakat sehingga kebijakan dan peraturan tersebut dapat membawa hasil sebagaimana yang diharapkan. Rangkaian kegiatan tersebut mencakup persiapan seperangkat peraturan lanjutan yang merupakan interpretasi dari kebijakan tersebut, misalnya dari sebuah Undang-Undang muncul sejumlah Peraturan Pemerintah, Keputusan Presiden, maupun Peraturan Daerah, menyiapkan sumber daya guna menggerakkan implementasi termasuk di dalamnya sarana dan prasarana, sumber daya keuangan, dan tentu saja siapa yang bertanggung jawab melaksanakan kebijakan tersebut, dan bagaimana mengantarkan kebijakan secara konkrit ke masyarakat.

Daniel A. Mazmanian dan Paul A. Sabatier menjelaskan makna implementasi, "Pelaksanaan keputusan kebijaksanaan dasar, biasanya dalam bentuk undangundang, namun dapat pula berbentuk perintah-perintah atau keputusan-keputusan eksekutif yang penting atau keputusan badan peradilan. Lazimnya, keputusan tersebut mengidentifikasikan masalah yang ingin diatasi, menyebutkan secara tegas tujuan atau sasaran yang ingin dicapai, dan berbagai cara untuk menstrukturkan atau mengatur proses implementasinya". ${ }^{13}$ Implementasi suatu peraturan pasti terdapat faktor pendukung dan faktor penghambat dalam pelaksanaannya khususnya mengenai implementasi PP No. 33 Tahun 2012 tentang Pemberian ASI Eksklusif.

\footnotetext{
${ }^{13}$ Mazmanian, Daniel A and Paul A. Sabatier. Implementation and Public Policy, Scott Foresman and Company, USA, 1983, hlm 139.
} 
Van Meter dan Van Horn menyatakan keberhasilan suatu implementasi kebijakan dipengaruhi oleh beberapa faktor, yaitu: ${ }^{14}$

a. Standar dan sasaran kebijakan/ukuran dan tujuan kebijakan;

Standar dan sasaran kebijakan yang diterapkan oleh Pemerintah Kota Palembang sebagai bentuk implementasi PP No. 33 Tahun 2012 dan Perda Kota Palembang No. 2 Tahun 2014 adalah adanya program dari Dinas Kesehatan Kota Palembang dalam implementasi peraturan tersebut, antara lain:

1) Mengadakan program kegiatan sosialisasi seputar ASI Eksklusif (PP ASI, manfaat ASI, dII) melalui kegiatan seminar dan pelatihan, sosialisasi tema kesehatan ASI di media cetak dan media massa di Kota Palembang.

2) Melakukan kerjasama banyak pihak khususnya organisasi bidang kesehatan dalam mendukung program ASI Eksklusif, kerjasama lintas program (surkesus) sejenis program usaha kesehatan pekerja dimana dilakukan pembinaan di perusahaan yang memiliki tenaga kerja wanita agar pekerja wanita dapat terpenuhi haknya untuk menyusui dan mendapatkan fasilitas khusus menyusui.

3) Membentuk swadaya masyarakat kelompok pendukung ASI seperti Ayah ASI dalam meningkatkan kesadaran masyarakat akan manfaat ASI Eksklusif.

4) Mengadakan kegiatan pelatihan teknis konseling dan konselor di fasilitas pelayanan kesehatan (rumah sakit, puskesmas, bidan praktik mandiri).

b. Sumber daya;

Keberhasilan proses implementasi kebijakan sangat tergantung dari kemampuan memanfaatkan sumberdaya yang tersedia. Hambatan yang dihadapi dalam upaya implementasi Peraturan Pemerintah tersebut adalah:

1) Faktor kurangnya pengetahuan ibu tentang menyusui.

2) Kurangnya tenaga konselor terlatih di rumah sakit.

3) Dukungan dari pemerintah yang masih seadanya belum maksimal.

c. Karakteristik dan organisasi pelaksana;

Tantangan menghadapi banyaknya promosi produk susu formula dengan tawaran yang menarik perhatian adalah harus dengan lebih menguatkan sosialisasi promosi ASI Eksklusif serta memberikan pengetahuan mengenai keunggulan dan kebaikan ASI dibandingkan susu formula serta meningkatkan kejasama dan koordinasi dengan aparat penegak hukum dalam memantau promosi tersebut. Untuk pelaporan masih belum efektif hanya berdasar menunggu adanya pengaduan dari masyarakat, tetapi Dinas Kesehatan berupaya mengingatkan dan memantau penggunaan susu formula di fasilitas pelayanan kesehatan dan akan bertindak tegas apabila terdapat oknum tenaga kesehatan yang melanggar.

d. Sikap para pelaksana;

Dalam menghadapi tantangan promosi harus didasari dari komitmen mendukung program ASI Eksklusif yang dicanangkan pemerintah sehingga tidak tertarik akan keuntungan semata dari promosi susu formula. Peraturan larangan promosi susu

\footnotetext{
${ }^{14}$ Van Meter and Van Horn, 1975, The Policy Implementation Process: A Conceptual Framework, Amsterdam: Van Meter and Van, hal. 142
} 
formula dan penggunaannya dipajang pada dinding rumah sakit guna memberikan sosialisasi dan edukasi kepada masyarakat akan adanya sanksi tegas larangan tersebut karna dapat menghambat program ASI Eksklusif. Lebih gencar lagi mempromosikan kebaikan ASI dibandingkan susu formula. Keseimbangan promosi akan ASI dapat menjadi strategi yang baik untuk memberikan pengetahuan kepada ibu menyusui.

e. Komunikasi antar organisasi terkait kegiatan-kegiatan pelaksanaan;

Dalam implementasi kebijakan khususnya PP No. 33 Tahun 2012 dan Perda Kota Palembang No. 2 Tahun 2014, Pemerintah Kota Palembang selalu berkoordinasi dengan pemerintah pusat dalam segala hal yang berkaitan dengan pemberian ASI Eksklusif. Hal tersebut dilaksanakan agar hambatan-hambatan dalam implementasi kebijakan tersebut dapat diselesaikan dengan baik.

f. Lingkungan sosial, ekonomi dan politik.

Hal terakhir yang perlu juga diperhatikan guna menilai kinerja implementasi publik dalam perspektif yang ditawarkan oleh Van Metter dan Van Horn adalah sejauh mana lingkungan eksternal turut mendorong keberhasilan kebijakan publik yang telah ditetapkan. Lingkungan sosial, ekonomi, dan politik yang tidak kondusif dapat menjadi biang keladi dari kegagalan kinerja implementasi kebijakan. Karena itu, upaya untuk mengimplementasikan kebijakan harus pula memperhatikan kekondusifan kondisi lingkungan eksternal.

Berdasarkan hasil penelitian melalui wawancara dan kenyataan dilapangan serta teori yang dipakai terkait dengan faktor pendukung dalam Implementasi Peraturan Pemerintah No. 33 Tahun 2012 tentang Pemberian ASI Eksklusif di Kota Palembang, didapatkan bahwa Kota Palembang telah memiliki Peraturan Daerah Nomor 2 Tahun 2014 tentang Pemberian ASI Eksklusif, dimana sebelumnya juga telah ada Perwali No. 60 Tahun 2012 yang mengatur pemberian ASI Eksklusif di Kota Palembang. Peraturan Daerah Nomor 2 Tahun 2014 tentang Pemberian ASI Eksklusif tersebut merupakan tindak lanjut dari Peraturan Pemerintah Nomor 33 Tahun 2012 tentang ASI Eksklusif.

Dinas Kesehatan Kota Palembang dalam implementasi peraturan tersebut memiliki program dimana Dinas Kesehatan berupaya melakukan pembinaan dan pemantauan ketersediaan fasilitas khusus menyusui diseluruh tempat Kota Palembang serta membuka layanan pengaduan bagi masyarakat agar dapat ditindaklanjuti. Adapun faktor pendukung menghadapi tantangan promosi susu formula yakni telah dilaksanakannya pencatatan dan pelaporan pada rekam medik dalam penggunaan susu formula oleh tenaga kesehatan ataupun fasilitas kesehatan serta bekerja sama dengan berbagai pihak dalam mengawasi kegiatan promosi susu formula yang dapat menghambat keberhasilan program ASI Eksklusif.

Komitmen dan kesadaran diri dari tenaga kesehatan dan fasilitas kesehatan sangat diharapkan dalam mendukung program ASI Eksklusif ini sehingga tidak mudah tertarik dalam kegiatan promosi susu formula bayi. Adapun kegiatan sosialisasi dari Dinas Kesehatan dengan menyebarkan/menempelkan leaflet berisikan aturan sanksi denda bila menghambat pemberian ASI Eksklusif hal ini bertujuan untuk memberikan edukasi kepada masyarakat. 
Berdasarkan hasil penelitian melalui wawancara dan kenyataan dilapangan serta teori yang dipakai terkait dengan faktor penghambat dalam Implementasi Peraturan Pemerintah No. 33 Tahun 2012 tentang Pemberian ASI Eksklusif di Kota Palembang, didapatkan bahwa faktor sosial dan budaya masyarakat, ibu yang bekerja, kurangnya tenaga konselor terlatih di rumah sakit, kurangnya dukungan partisipasi masyarakat khususnya keluarga akan ASI Eksklusif sehingga tidak adanya laporan keluhan yang bisa ditindaklanjuti, kurangnya SDM dalam melakukan pemantauan kunjungan ke seluruh fasilitas sarana prasarana di Kota Palembang, pengaruh paparan iklan promosi susu formula yang dapat merubah sikap ibu, penegakan hukum yang kurang tegas dimana belum ada kejasama dan koordinasi dengan aparat penegak hukum dalam memantau promosi susu formula, sosialisasi peraturan yang kurang kepada masyarakat sehingga masyarakat tidak tahu manfaat peraturan tersebut.

3. Tanggung Jawab Pemerintah Kota Palembang dalam Implementasi Peraturan Pemerintah No. 33 Tahun 2012 tentang Pemberian ASI Eksklusif sebagai Bentuk Perlindungan Hukum bagi Bayi terhadap Promosi Susu Formula Bayi di Kota Palembang

Tanggung jawab adalah kewajiban untuk memikul pertanggungjawaban dan hingga memikul kerugian (bila dituntut atau jika dituntut) baik dalam kaitan dengan hukum maupun dalam administrasi. ${ }^{15}$ Sedangkan pemerintahan diletakkan dalam dua arti yaitu arti luas dan sempit. ${ }^{16}$ Pemerintahan dalam arti luas adalah segala bentuk kegiatan atau aktivitas penyelenggara negara yang dilakukan oleh organ-organ atau alat-alat perlengkapan negara yang memiliki tugas dan fungsi sebagaimana digariskan oleh konstitusi. Pengertian seperti ini mencakup kegiatan atau aktivitas penyelenggaraan negara yang dilakukan oleh Eksekutif, Legislatif dan Yudikatif dalam suatu organisasi kekuasaan yang disebut negara. Pengertian Pemerintahan dalam arti sempit tidak lain adalah aktivitas atau kegiatan yang diselenggarakan oleh organ pemegang kekuasaan eksekutif sesuai dengan tugas dan fungsinya yang dalam hal ini dilaksanakan oleh Presiden ataupun Perdana Menteri sampai dengan level birokrasi yang paling rendah tingkatannya. Dengan kata lain, penyelenggaraan tugas dan fungsi Administratuur atau bestuur yang disebut sebagai pemerintahan dalam arti sempit.

Pemerintah berkewajiban dan bertanggung jawab terhadap penyelenggaraan perlindungan anak khususnya berkaitan dengan pelayanan dasar kesehatan hal ini telah diatur di dalam ketentuan Undang-Undang Nomor 23 Tahun 2014 tentang Pemerintahan Daerah pada Pasal 12 Ayat (1) huruf b dan Pasal 12 Ayat (2) huruf b. Tanggung jawab pemerintah dalam tulisan ini dimaksudkan sebagai tanggung jawab memenuhi ketentuan Peraturan Pemerintah Nomor 33 Tahun 2012 tentang Pemberian ASI Eksklusif. Peran pemerintah dalam rangka pemberian ASI Eksklusif secara tegas dinyatakan dalam Pasal 129 ayat (1) Undang-Undang Nomor 36 Tahun 2009 Tentang Kesehatan yang menyatakan bahwa Pemerintah bertanggung jawab menetapkan kebijakan dalam rangka menjamin hak bayi untuk mendapatkan air susu ibu secara eksklusif. Mengenai tanggung jawab pemerintah

\footnotetext{
${ }^{15}$ Nasution, 2011, Pertanggungjawaban Gubernur dalam Negara Kesatuan Indonesia, Jakarta: PT. Sofmedia, hal. 48.

${ }^{16}$ B. Hestu C. Handoyo, 2009, Hukum Tata Negara Indonesia, Yogyakarta: Universitas Atma Jaya Yogyakarta, hal. 119.
} 
juga diatur dalam Pasal 14 Undang-Undang Nomor 36 Tahun 2009 Tentang Kesehatan yang menyatakan bahwa pemerintah bertanggung jawab merencanakan, mengatur, menyelenggarakan, membina, dan mengawasi penyelenggaraan upaya kesehatan yang merata dan terjangkau oleh masyarakat.

Pemerintah mempunyai tugas dan tanggung jawab terhadap konsumen dalam penyediaan pelayanan kesehatan yang baik, termasuk pelayanan tenaga kesehatan dalam pemberian informasi tentang ASI Eksklusif, dimana semakin maraknya promosi susu formula bayi. Untuk melindungi masyarakat dari adanya promosi susu formula yang menghambat pemberian ASI Eksklusif, pemerintah telah menetapkan Peraturan Pemerintah (PP) Nomor 33 Tahun 2012 mengenai Pemberian ASI Eksklusif pada 1 Maret 2012. Tanggung jawab Pemerintah khususnya Pemerintah Daerah Kabupaten/Kota dalam program pemberian ASI Eksklusif diatur dalam Pasal 5 Peraturan Pemerintah (PP) Nomor 33 Tahun 2012 tentang Pemberian ASI Eksklusif dan Pasal 3 Perda Kota Palembang Nomor 2 Tahun 2014 tentang Pemberian ASI Eksklusif meliputi:

a. Melaksanakan kebijakan nasional dalam rangka program pemberian ASI Eksklusif;

b. Melaksanakan advokasi dan sosialisasi program pemberian ASI Eksklusif dalam wilayah Kota;

c. Memberikan pelatihan teknis konseling menyusui dalam wilayah Kota;

d. Menyediakan tenaga konselor menyusui di Failitas Pelayanan Kesehatan dan tempat sarana umum lainnya dalam skala Kota;

e. Membina, monitoring, mengevaluasi, dan mengawasi pelaksanaan dan pencapaian program pemberian ASI Eksklusif di Fasilitas Pelayanan Kesehatan, satuan pendidikan kesehatan, tempat kerja, tempat sarana umum dan kegiatan di masyarakat dalam wilayah Kota;

f. Menyediakan tenaga konselor menyusui di Puskesmas dan Rumah Sakit Umum Daerah sedangkan untuk rumah sakit swasta, rumah sakit bersalin dan bidan praktek swasta diwajibkan menyediakan tenaga konselor;

g. Mengembangkan kerjasama dengan pihak lain sesuai dengan ketentuan peraturan perundang-undangan; dan

h. Menyediakan ketersediaan akses terhadap informasi dan edukasi atas penyelenggaraan pemberian ASI Eksklusif dalam wilayah Kota. ${ }^{17}$

Berdasarkan hasil penelitian melalui wawancara dan kenyataan dilapangan serta teori yang dipakai terkait dengan tanggung jawab pemerintah dalam Implementasi Peraturan Pemerintah No. 33 Tahun 2012 tentang Pemberian ASI Eksklusif di Kota Palembang, didapatkan bahwa Pemerintah Kota Palembang telah menjalankan tanggung jawabnya dalam mendukung pelaksanaan program ASI Eksklusif sesuai Pasal 5 Peraturan Pemerintah (PP) Nomor 33 Tahun 2012 tentang Pemberian ASI Eksklusif dan Pasal 3 Perda Kota Palembang Nomor 2 Tahun 2014 tentang Pemberian ASI Eksklusif yakni diantaranya melaksanakan

\footnotetext{
${ }^{17}$ Pasal 5 Peraturan Pemerintah (PP) Nomor 33 Tahun 2012 tentang Pemberian ASI Eksklusif dan Pasal 3 Perda
} Kota Palembang Nomor 2 Tahun 2014 tentang Pemberian ASI Eksklusif. 
kebijakan nasional dengan menerbitkan Perda Kota Palembang Nomor 2 Tahun 2014 tentang Pemberian ASI Eksklusif untuk mendukung program ASI Eksklusif di Kota Palembang.

Pemerintah Kota Palembang khususnya Dinas Kesehatan Kota Palembang telah melaksanakan advokasi dan sosialisasi program pemberian ASI Eksklusif kepada masyarakat, tenaga kesehatan, dan fasilitas kesehatan dengan mengadakan berbagai seminar mengenai ASI Eksklusif, membentuk gerakan kelompok pendukung ASI, melakukan promosi kesehatan setiap bulannya melalui radio dan tv swasta di Kota Palembang. Dinas Kesehatan telah melakukan kerja sama dengan beberapa pihak dalam program ASI Eksklusif diantaranya organisasi profesi kesehatan, kerjasama lintas program (surkesus) sejenis program usaha kesehatan pekerja dimana dilakukan pembinaan di perusahaan yang memiliki tenaga kerja wanita dapat terpenuhi haknya untuk menyusui dan mendapatkan fasilitas khusus menyusui.

Pelatihan teknis konseling menyusui juga telah dilaksanakan oleh Dinas Kesehatan namun dalam pelaksanaannya baru diadakan beberapa kali saja dan belum rutin terjadwal. Dinas Kesehatan telah menyediakan tenaga konselor menyusui di fasilitas pelayanan kesehatan namun sebarannya belum merata karena jumlah tenaga konselor yang dimiliki hanya 52 orang sehingga hanya beberapa tempat saja yang tersedia tenaga konselor dan untuk sarana umum masih belum terdapat tenaga konselor. Ketersediaan akses terhadap informasi dan edukasi atas penyelenggaraan pemberian ASI Eksklusif dilakukan Dinas Kesehatan melalui kegiatan promosi kesehatan di radio dan tv swasta di Kota Palembang, penyebaran leaflet/poster berisikan kebaikan manfaat ASI serta membuka layanan pengaduan masyarakat terkait ASI Eksklusif di Kota Palembang.

Pemerintah Kota Palembang dan Dinas Kesehatan telah berupaya dalam pembinaan, monitoring, evaluasi dan pengawasan pencapaian program ASI Eksklusif dengan melalui forum pemantauan dari posyandu yang kemudian melaporkan pada puskesmas. Ditingkat puskesmas, data diolah lalu setiap bulan dilaporkan pada Dinas Kesehatan. Evaluasi dilakukan oleh Dinas Kesehatan khususnya bagian gizi dimana dilakukan monitoring setahun 2 kali di bulan februari dan agustus pada saat bintek dan setiap akhir periode program pada saat evaluasi program gizi secara keseluruhan.

Tugas dan tanggung jawab Pemerintah Kota Palembang khususnya dalam menghadapi promosi susu formula bayi juga tercantum di dalam Pasal 3 dan Pasal 5 Peraturan Menteri Kesehatan Republik Indonesia Nomor 39 Tahun 2013 Tentang Susu Formula Bayi dan Produk Bayi Lainnya yaitu :

a. Meningkatkan pengetahuan dan kesadaran masyarakat akan pentingnya pemenuhan gizi pada bayi dengan memberikan ASI Eksklusif;

b. Membina dan mengawasi periklanan dan promosi Susu Formula Bayi dan Produk Bayi Lainnya;

c. Melakukan pengawasan terhadap penggunaan Susu Formula Bayi dan Produk Bayi Lainnya di masyarakat dan dalam situasi darurat dan/atau bencana; 
d. Meningkatkan pengetahuan kepada masyarakat tentang penggunaan Susu Formula Bayi dan Produk Bayi Lainnya secara aman; dan

e. Menerima laporan pengaduan dari masyarakat. ${ }^{18}$

Terkait tanggung jawab pemerintah terhadap promosi susu formula bayi yang dapat mempengaruhi program ASI Eksklusif Dinas Kesehatan telah berupaya melakukan pembinaan kepada tenaga kesehatan dan fasilitas kesehatan akan larangan mempromosikan susu formula bayi, monitoring baru dilakukan hanya beberapa kali di beberapa fasilitas pelayanan kesehatan dan tempat umum ataupun tempat perbelanjaan, dan pengawasan masih kurang efektif karena mengandalkan pengaduan dari masyarakat bahkan dalam pengawasannya Dinas Kesehatan Kota Palembang belum bekerja sama dengan pihak BPOM.

Pemerintah Kota Palembang khususnya Dinas Kesehatan Kota Palembang secara keseluruhan telah melaksanakan tanggung jawabnya sesuai Peraturan ASI Eksklusif walaupun dalam implementasinya masih terdapat kekurangan dan belum berjalan optimal khususnya tanggung jawab pemerintah dalam memberikan perlindungan bagi bayi terhadap promosi susu formula karena belum ada bentuk sanksi yang tegas dan nyata dalam pelaksanaannya akibat kendala kurangnya koordinasi dengan instansi terkait.

Berdasarkan uraian yang ada dapat dinyatakan bahwa tanggung jawab pemerintah dalam implementasi PP No. 33 Tahun 2012 tentang Pemberian ASI Eksklusif sebagai bentuk perlindungan hukum bagi bayi terhadap promosi susu formula bayi di Kota Palembang adalah tanggung jawab dalam menjalankan Perda Kota Palembang Nomor 2 Tahun 2014 tentang Pemberian ASI Eksklusif sebagai tindak lanjut dari Peraturan Pemerintah (PP) Nomor 33 Tahun 2012 tentang Pemberian ASI Eksklusif dan dalam memberikan perlindungan hukum bagi bayi terhadap promosi susu formula pemerintah bertanggung jawab menjalankan penerapan sanksi yang tegas dan nyata bagi yang melanggar dan menghambat pemberian ASI Eksklusif.

\section{PENUTUP}

\section{KESIMPULAN}

Berdasarkan uraian dan analisis pada bab-bab terdahulu, berikut disajikan kesimpulan yang merupakan jawaban terhadap permasalahan dalam penelitian ini, yaitu:

a. Implementasi PP No. 33 Tahun 2012 Tentang Pemberian ASI Eksklusif belum berjalan dengan optimal dalam memberikan perlindungan hukum bagi bayi terhadap promosi susu formula bayi di Kota Palembang hal tersebut terlihat dari pelaksanaan sistem mekanisme pembinaan, pengawasan, dan penegakan hukum sanksi yang belum jelas dan tegas dari Pemerintah (Dinas Kesehatan Kota Palembang), BPOM, dan organisasi profesi kesehatan.

\footnotetext{
${ }^{18}$ Pasal 3 dan Pasal 5 Peraturan Menteri Kesehatan Republik Indonesia Nomor 39 Tahun 2013 tentang Susu Formula Bayi Dan Produk Bayi Lainnya
} 
b. Faktor pendukung dalam implementasi Peraturan Pemerintah No. 33 Tahun 2012 tentang Pemberian ASI Eksklusif sebagai bentuk perlindungan hukum bagi bayi terhadap promosi susu formula bayi di Kota Palembang adalah Kota Palembang telah memiliki Perda yang mengatur ASI Eksklusif yakni Perda No. 2 Tahun 2014 tentang Pemberian ASI Eksklusif Sebagai tindak lanjut dari PP No. 33 Tahun 2012 serta dimana sebelumnya juga telah ada Perwali No. 60 Tahun 2012 yang mengatur pemberian ASI Eksklusif di Kota Palembang.

c. Faktor penghambat dalam implementasi Peraturan Pemerintah No. 33 Tahun 2012 tentang Pemberian ASI Eksklusif sebagai bentuk perlindungan hukum bagi bayi terhadap promosi susu formula bayi di Kota Palembang, antara lain: faktor sosial dan budaya masyarakat, ibu yang bekerja, kurangnya tenaga konselor terlatih di rumah sakit, kurangnya dukungan partisipasi masyarakat khususnya keluarga akan ASI Eksklusif sehingga tidak adanya laporan keluhan yang bisa ditindaklanjuti, kurangnya SDM dalam melakukan pemantauan kunjungan ke seluruh fasilitas sarana prasarana di Kota Palembang, pengaruh paparan iklan promosi susu formula yang dapat merubah sikap ibu, penegakan hukum yang kurang tegas dimana belum ada kejasama dan koordinasi dengan aparat penegak hukum dalam memantau promosi susu formula, sosialisasi peraturan yang kurang kepada masyarakat sehingga masyarakat tidak tahu manfaat peraturan tersebut.

d. Tanggung jawab pemerintah dalam implementasi PP No. 33 Tahun 2012 tentang Pemberian ASI Eksklusif sebagai bentuk perlindungan hukum bagi bayi terhadap promosi susu formula bayi di Kota Palembang adalah tanggung jawab dalam menjalankan Perda Kota Palembang Nomor 2 Tahun 2014 tentang Pemberian ASI Eksklusif sebagai tindak lanjut dari Peraturan Pemerintah (PP) Nomor 33 Tahun 2012 tentang Pemberian ASI Eksklusif dan dalam memberikan perlindungan hukum bagi bayi terhadap promosi susu formula pemerintah bertanggung jawab menjalankan penerapan sanksi yang tegas dan nyata bagi yang melanggar dan menghambat pemberian ASI Eksklusif.

\section{SARAN}

a. Pemerintah dan Dinas Kesehatan Kota Palembang untuk lebih meningkatkan sosialisasi pemberian ASI Eksklusif dan peraturannya secara luas dan berkelanjutan melalui inovasi media massa atau media cetak agar masyarakat sadar hukum dan paham akan hak dan kewajibannya untuk ikut berperan aktif mendukung program ASI Eksklusif serta meningkatkan kerjasama membentuk tim khusus yang beranggotakan unsur terkait dalam pembinaan dan pengawasan program ASI Eksklusif khususnya pengawasan penyalahgunaan promosi susu formula.

b. Tenaga kesehatan dan fasilitas kesehatan Rumah Sakit untuk lebih meningkatkan komitmen, kesadaran diri, dan peran aktifnya dalam mendukung program pemberian ASI Eksklusif dengan memenuhi ketentuan yang ada dalam Peraturan Pemerintah seperti Rumah Sakit membuat kebijakan tertulis tentang pemberian ASI Eksklusif yang rutin dikomunikasikan kepada seluruh tenaga kesehatan serta dapat secara mandiri membentuk suatu kelompok kerja (kelompok pendukung $\mathrm{ASI}$ ) dalam memberikan dukungan untuk menyusui. 
c. Masyarakat sebagai pengguna layanan juga harus berperan aktif dalam keberhasilan program ASI Eksklusif, karena tanpa adanya dukungan dan pencegahan dari masyarakat sendiri program ASI Eksklusif ini tidak akan dapat tercapai, selain itu peran kelompok pendukung ASI yang sudah ada dapat terus ditingkatkan agar masyarakat semakin sadar akan pentingnya pemberian ASI Eksklusif.

\section{DAFTAR PUSTAKA}

A. Mustofa, dan H. Prabandari, "Pemberian ASI Eksklusif dan Problematika Ibu Menyusui”, 2010, Yinyang, Vol 5 No 2 Jul-Des 2010 ISSN: 1907-2791

Arifin Siregar, 2004, Faktor-Faktor yang Mempengaruhi Pemberian ASI Oleh Ibu Melahirkan [serial online]. Medan: Bagian Gizi Kesehatan Masyarakat Fakultas Kesehatan Masyarakat Universitas Sumatra Utara. http://library,usu.ac.id/download/ fkm/fkmarifin-pdf. [diakses 13 Januari 2017]

B. Hestu C. Handoyo, 2009, Hukum Tata Negara Indonesia, Yogyakarta: Universitas Atma Jaya Yogyakarta

Briawan Dodik, 2004, Pengaruh Promosi Susu Formula terhadap Pergeseran Penggunaan Air Susu Ibu (ASI), Program Doktor, Sekolah Pascasarjana IPB

Dinas Kesehatan Kota Palembang, 2014, Profil Kesehatan Kota Palembang, Palembang

Dinas Kesehatan Kota Palembang, 2016, Profil Kesehatan Kota Palembang, Palembang

Mazmanian, Daniel A and Paul A. Sabatier.1983, Implementation and Public Policy, Scott Foresman and Company, USA.

Nasution, 2011, Pertanggungjawaban Gubernur dalam Negara Kesatuan Indonesia, Jakarta: PT. Sofmedia

Peraturan Menteri Kesehatan No. 39 Tahun 2013 tentang Susu Formula Bayi dan Produk Bayi Lainnya

PP No. 33 Tahun 2012 tentang Pemberian ASI Eksklusif

Profil Kesehatan Indonesia Tahun 2013.

Soerjono Soekanto, 1986, Pengantar Penelitian Hukum, Jakarta: Penerbit Universitas Indonesia , 2015, Pengantar Penelitian Hukum Cetakan Ketiga, Jakarta: Penerbit Universitas Indonesia

Suradi R., 2008, Manfaat ASI \& Kerugian Susu Formula, Jakarta: Balai Penerbit FKUI

Van Meter and Van Horn, 1975, The Policy Implementation Process: A Conceptual Framework, Amsterdam: Van Meter and Van Horn 